\title{
Činnost Ruské pravoslavné církve v Abcházii a Jižní Osetii: v souladu s pozicí ruského státu nebo $v$ rozporu s ní?
}

\author{
The activity of the Russian Orthodox \\ Church In Abkhazia and South Ossetia: in \\ accordance with the position of the \\ Russian state, or contrary to it?
}

Acta Fakulty filozofické Západočeské univerzity v Plzni 2019, Vol. 11 (2), 40-56 DOl: https://doi.org/10.24132/actaff.2019.11.2.3 http://ff.zcu.cz/research/edicni-cinnost/acta/ ISSN 2336-6346

\author{
Maria Avanesova* \\ Západočeská univerzita v PIzni
}

\begin{abstract}
The purpose of this text is to attempt to provide a basic outline of the Russian Orthodox Church's activities in Abkhazia and South Ossetia. The Russian Orthodox Church (ROC), which is considered to be the largest autocephaly Orthodox Church in the world, is active not only in Russia but also outside Russia. This is made possible through the "several states - one patriarchate" formula adopted by the ROC for the activities of other Orthodox churches in its canonical territory. However, the activity of the Church is also visible outside the canonical space. Close cooperation between the ROC and the Russian state within Russia and the support of the $\mathrm{ROC}$ in its work both inside and outside the canonical territory make it possible to discuss the interconnection between the state and the Church. One of the few examples in which the positions of the Russian Orthodox Church and the Russian state are different are relations between the Russian Orthodox Church and the state towards Abkhazia and South Ossetia. The aim of this text is to compare the attitude of the Russian state and the Church to Abkhazia and South Ossetia. The analysis will proceed in two ways. The first will be the relationship of Russia and ROC to Abkhazia and South Ossetia's ecclesiastical affiliation. The other direction will be the relationship to the "statehood" of South Ossetia and Abkhazia. This paper, which is based mainly on the analysis of primary sources (state and Church websites), is structured chronologically. The study shows that the state and Church positions are very similar and do not contradict one another.
\end{abstract}

\section{Keywords}

Russia, patriarch, Russian Orthodox Church, Abkhazia, South Ossetia

\footnotetext{
* Corresponding Author: Maria Avanesova, Katedra politologie a mezinárodních vztahů, Fakulta filozofická Západočeské univerzity v Plzni, Jungmannova 1, 30100 Plzeň. E-mail: avanesova@kap.zcu.cz.
} 


\section{Úvod}

Ruská pravoslavná církev (RPC), jejíž činnosti v Jižní Osetii a Abcházii je věnován daný text, je považována za největší centralizovanou náboženskou organizaci v postsovětském prostoru (Mitrokhin, Nuritova, Kishkovsky 2009: 289) a je největší autokefální pravoslavnou církví. Občanský řád RPC uvádí, že jurisdikce Ruské pravoslavné církve zahrnuje osoby pravoslavného vyznání žijící v postsovětském prostoru, s výjimkou Gruzie a Arménie, a rovněž pravoslavné věřící žijící v Č́ně, Mongolsku, Japonsku a také dobrovolně připojené ortodoxní křestany žijící v jiných zemích (RPC MP 2017a). To znamená, že bez ohledu na státní hranice považuje RPC činnost na svém kanonickém území za vnitřní záležitost. Pojem „kanonické území“ a požadavek na jeho dodržování se objevily mezi představiteli ruské církve v průběhu 90 . let. Během daného období představitelé RPC přijali církevní formuli „Několik států - jeden patriarchát“, což znamenalo, že hranice patriarchátu se nemusí nutně shodovat se státními hranicemi, protože patriarchát není politický, národní či zeměpisný pojem (Bezborodov 2010: 84; Rjabych 2004: 140). Zmíněná formule také poukazovala na to, že rozpad sekulární federace nemůže být dostatečným důvodem pro porušení svaté jednoty církve (Curanović 2012: 133). Činnost jiných pravoslavných církví, například Konstantinopolského patriarchátu, na kanonickém území RPC byla a je ruským církevním, ale i světským vedením odsuzována. I mimo vlastní kanonické území je RPC značně aktivní a z velké části je také podporována vedením ruského státu.

Úzká spolupráce mezi RPC a ruským státem uvnitř Ruska a podpora RPC v její činnosti na kanonickém území i mimo něj ze strany ruského světského vedení vedly ke vzniku publikací, které jsou věnovány roli RPC v ruské zahraniční politice (Leustean 2014, Richters 2013; Curanović 2012; Knox 2005). V souvislosti se situací na Ukrajině vzniklo mnoho publikací na toto téma a je spojeno s otázkou ruské propagandy, využitím RPC jako státní soft power nebo legitimizačního nástroje politiky ruského vedení (např. Avanesova, Naxera 2018; Shafiee, Fallahi 2018; Petro 2015; Hudson 2018 apod.).

V samotném Rusku se lze setkat s velice protichůdnými názory ohledně spolupráce státu a církve v zahraničněpolitických otázkách. Například, předseda Mezinárodního fondu jednoty pravoslavných národů Valerij Alexejev (2016), který má blízko k vedení RPC, uvádí, že RPC se nepodílí na zahraniční politice Ruska a že stát se zajímá o názor RPC pouze v některých př́ípadech (například v otázkách týkajících se Balkánu). Podobný názor má i pracovník Ruského ústavu strategického výzkumu Andrej Serebrič (2016), který ovšem uvedl, že i když RPC nemá takovou sílu, aby ovlivnila rozhodnutí ministerstva zahraničních věcí, je vlivným aktérem, který může působit na veřejné mínění. Právě to může využít stát ve svůj prospěch. Naopak o spolupráci RPC a státu v oblasti zahraniční politiky a o RPC jakožto nástroji ruské soft power mluví např́iklad Nikolaj Baranov (2016). Otec Alexandr Šumskij (2016), významný duchovní v ruských pravoslavných kruzích, uvádí, že RPC je dnes jedním z nejdůležitějších pomocníků státu v zahraniční politice. Olga Cerpickaja (2016) a Olga Sibireva (2016) uvádějí, že RPC je využívána státem jako legitimizační nástroj. Objevují se také názory, že RPC může realizovat vlastní program, např́íklad může být mediátorem v konfliktních situacích.

Př́ḱlad Abcházie a Jižní Osetie nebyl vybrán náhodně. Podle názoru odborníků je to jedna z mála situací, kdy pozice RPC a ruského státu byly v rozporu. Lze se setkat $\mathrm{s}$ argumentem, že tento postoj RPC se projevoval tak, že ani oblasti, ani politiku ruského vedení nepodpořila, protože nekomentovala ruskou činnost (Krutinskaja 2008), neudělila církvím autonomii a nevzala je pod svou jurisdikci (Payne 2015: 69; Lunkin 2018: 72; Chedia 2009: 198). S podobným názorem se lze setkat i v projevech mimo akademickou obec, např́klad u jihoosetských politiků (např. Russkaja linija 2009).

Cílem předloženého textu je na př́kladu vztahu RPC vůči Jižní Osetii a Abcházii analyzovat názorovou shodu RPC s politikou ruského státu. Vzhledem k tomu, že jmenované de facto státy 
jsou součástí jurisdikce Gruzínské církve, znamená to, že pro RPC, stejně jako pro ruský stát, se jedná o oblasti vnější činnosti. Z toho vyplývá, že předložený text by mohl přispět k debatě o celkové roli RPC v ruské zahraniční politice, nikoliv pouze v postsovětském prostoru.

Analýza bude probíhat ve dvou směrech. Prvním bude vztah RPC k církevní příslušnosti Abcházie a Jižní Osetie. Oficiální rétorika představitelů RPC bude porovnána s faktickými kroky RPC, které byly dohledány v ruských a místních médiích, nebo na webových stránkách církví. Druhým směrem bude vztah RPC ke „státnosti“ Jižní Osetie a Abcházie. Vzhledem k tomu, že politika světského vedení Ruska je všeobecně známá, bude jí věnována jen okrajová pozornost. Práce se zaměří především na postoj RPC vůči Abcházii a Jižní Osetii. Časově bude práce zachycovat období od rozpadu SSSR do současnosti.

Zdrojovou základnou pro předložený text budou: web RPC (http://www.patriarchia.ru/) slova vyhledávání na webu ruské církve: „Jižní Osetie“, „Abcházie“; oficiální web Abchazské pravoslavné církve (http://www.aiasha.ru/), Svaté metropolie Abcházie (https://anyha.org/) slova vyhledávání: Rusko, Ruská pravoslavná církev, RPC, Alexij II., Kirill. Dalšími zdroji jsou jihoosetská, abchazská a ruská média. Kritériem pro volbu médií bylo obsažení klíčových slov (slova vyhledávání) a jejich (aspoň částečná) afilace se státem/de facto státy nebo církví. V případě Jižní Osetie a Abcházie klíčovými slovy byla slova: Ruská pravoslavná církev, RPC, Alexij II., Kirill. V případě Ruska - církev v Jižní Osetii, jihoosetská církev, církev v Abcházii, abchazská církev, Vissarion Aplia (Apliaa), Georgij Puchajev (Puchate). Sekundárními zdroji jsou i odborné práce věnující se danému tématu.

Text bude rozdělen do tři částí a části závěrečné. První část krátce nastíní vývoj církevní situace v Abcházii a Jižní Osetii do poloviny 90.let, protože současná církevní situace v předložených de facto státech je v mnohém ozvěnou situace z 90. let. Druhá a třetí části se zaměří na téma vývoje vztahu RPC vůči Abcházii a Jižní Osetii do roku 2008 a od roku 2008 do současnosti.

\section{Církevní situace během sovětského období a na začátku 90. let}

Během sovětského období příslušnost církevních jurisdikcí na území Jižní Osetie a Abcházie nebyla důležitou otázkou. RPC pod nátlakem Stalina a na jeho speciální doporučení v roce 1943 obětovala Abcházskou diecézi ve prospěch gruzínské pravoslavné církve (Conroy 2015: 629). Současné vedení Abcházské církve připojení ke gruzínské církvi považuje za nelegitimní (Dbar 2006:17; Aplia cit. dle Tjurenkov 2019). V každém případě, Abcházie byla během sovětského období považována za místo, kde existovala pro duchovní určitá svoboda a vládní orgány zde pronásledovaly pravoslavné v minimální míře. Do Abcházie proto přišli také ještě mnozí radikální představitelé RPC z celého SSSR (Mitrochin 2004: 519; Dbar 2006:18). Jižní Osetie byla výrazně sovětizovaná, což umožnuje mluvit o tom, že komunita pravoslavných věřících v Jižní Osetii byla velmi malá (pouze několik farníků, kteří se scházeli v jednom existujícím chrámu, jenž byl ve špatném stavu) (Mitrochin 2004: 520). Dnes se ovšem tvrdí, že jihoosetská církev nikdy ke gruzínské církvi nepatřila (např. Južnaja Osetija segodnja 2018; Sekritariat Alanskoj eparchii 2008).

Situace se pro obě oblasti změnila s nástupem Zviada Gamsachurdii do čela Gruzie. Rostoucí úloha GPC v gruzínské společnosti díky mottu „Gruzie pro Gruzíny “ v neposlední řadě přispěla k propojení náboženství a nacionalismu, což v gruzínských podmínkách té doby vedlo k růstu religiozity v zemi (Conroy 2015: 627) a budování obrazu křestanské Gruzie. Vytvoření tohoto obrazu bylo spjato s budováním obrazu nepřátel, kteří vyznávají islám. Podobný obraz umožnil gruzínským médiím mluvit o Abcházech jako muslimech, kteří jsou spojeni s muslimskými fundamentalisty a chtějí vytvořit islámský stát, aby odtrhli Gruzii od křestanského světa ${ }^{1}$ (Šnirelman

\footnotetext{
${ }^{1}$ Je pravdou, že během války mezi Abcházií a Gruzií v 90. letech za Abcházce bojovala skupina islamistů, vedená Šamilem Basajevem, která v boji viděla možnost oživení abcházského islámu, jenž byl během sovětské éry zničen.
} 
2003: 436-440). Tento argument také umožňoval ospravedlnit válku v Abcházii v očích gruzínské veřejnosti. Taková situace ovšem měla negativní dopad na veřejné mínění v Abcházii, kde odpovědnost připisovali i GPC.

Činnost duchovních Gruzínské pravoslavné církve - Gruzínů, kteří sloužili v Abcházii, také přispívala ke zhoršení obrazu GPC v řadách abcházské veřejnosti. Gruzínští duchovní byli obviňováni abcházskými duchovními z participování na politických akcích gruzínských nacionalistů na území Abcházie, z podpory války proti Abcházii a nařčeni z radosti z dobytí Suchumi gruzínskými „bandity“ (Dbar 2006:18; Silant̉jev 2007: 138-139). Abcházští političtí činitelé obviňovali představitele GPC z toho, že způsobili prohloubení etnopolitických neshod a dávali požehnání „zločinům proti lidskosti“ (Svjaščennaja metropolija Abchazija nedat.a; Hoch, Khundadze 2017: $13)$.

Pro představitele Jižní Osetie a Abcházie hraje důležitou roli i osobnost Ilii II., který je od roku 1977 v čele GPC. V Abcházii je považován za hlavního strůjce gruzínského nacionalismu a vojenské agrese v 90. letech (Conroy 2015: 629). Představitelé Jižní Osetie obviňují Iliu II. z podpory politiky Gamsahurdii, z vojenské kampaně - genocidy jihoosetského národa a provinciálního fašismu (RPC MP 2007a). Představitelé obou de facto států se odvolávají na projev Ilii II. z roku 1991, ve kterém prohlásil, že každý, kdo zabije Gruzína, bude prohlášen za nepřítele gruzínského lidu (IA Alanijainform 2011; Hoch, Khundadze 2017: 13).

Válka mezi těmito oblastmi a Gruzií fakticky znemožnila participaci GPC na náboženském životě v Jižní Osetii a Abcházii. V obou oblastech byla a je existence církve nezávislé na Gruzii považována za nezbytnou podmínku pro samostatnou státní existenci a je vnímána jako jedna z nutných podmínek „státní“ bezpečnosti (Conroy 2015: 629; Prezident Južnoj Osetii 2013).

V záŕí roku 1993, po dobytí Suchumi abcházskou armádou, museli gruzínští duchovní Abcházii opustit (gruzínský biskup je dodnes oficiálně v čele Abcházské eparchie, i když na území Abcházie nemá přístup). V Jižní Osetii gruzínský metropolita po válce v 90. letech zůstal. Pod jeho správou byly však spíše oblasti, ve kterých žili převážně etničtí Gruzíni (Soldatov 2008:1). To vedlo k tomu, že z církevního hlediska vznikla potřeba bud' existence vlastní církve nebo začlenění do jiné pravoslavné církve (Conroy 2015: 630; Hoch, Khundadze 2017: 13). ${ }^{2}$

\section{Vývoj vztahů RPC vůči Jižní Osetii a Abcházii do roku 2008}

V Abcházii ještě z dřívějších dob existovala církevní infrastruktura, včetně dvou klášterů (Mitrochin 2004: 520). Po válce na území Abcházie zůstali pouze 4 duchovní (jeden Abcház a tři Rusové), ovšem ani jeden z nich nebyl v hodnosti arcibiskupa, což by umožňovalo vysvětit další duchovní, aby církev mohla fungovat, i kdyby nebyla nikým uznána. Bez ohledu na tento fakt na konci roku 1993 duchovní zvolili Vissariona Apliaa (někde také Aplia) představitelem Suchumo-abcházské pravoslavné církve pro vztahy mezi církví a státem a církví a RPC. V roce 1998 byla kvůli absenci vládnoucího biskupa na území Abcházie založena Diecézní rada Abcházie, jejímž předsedou byl zvolen Apliaa (Dbar 2006: 18-19). Vzhledem k tomu, že rada zahrnovala jak duchovní, tak i laiky, získal její předseda poměrně legitimní příležitost, aby se prohlásil za vůdce pravoslavné komunity republiky (Silantjev 2007: 139).

Stejný názor měly částečně i turecké struktury a abcházští repatrianti, kteří se začali vracet z Turecka (Silantjjev 2007: 137). Ovšem, podle dostupných zdrojů, nelze po rozpadu SSSR hovořit o významném islámském faktoru v abcházské politice. Počet muslimů v postsovětské Abcházii nebyl nikdy výrazný (Agababyan 2016: 78; Grigorjan 2006).

${ }^{2}$ Je třeba poznamenat, že podle průzkumu z roku 1997 se většina obyvatel Abcházie hlásila k pravoslaví. Zároveň většina těch, kdo se hlásili k pravoslaví, přiznali, že věří v místní pohanské symboly a váží si jich (Krylov 1999: 148). Úcta k pohanským symbolům a pohanským praktikám je podporována i po roce 2000 ze strany abcházského vedení (Agababyan 2016:78-85). 
Otázka příslušnosti abcházské církve zajímala ovšem nejen abcházské duchovní, ale i světské činitele, kteří také hledali podporu u RPC. Abcházský prezident se obrátil na ruského patriarchu s žádostí, aby bez ohledu na jakékoliv politické a byrokratické překážky bylo Abcházcům umožněno vzdělávat se $\mathrm{v}$ kněžských seminářích a na duchovních akademiích, pokud o to projeví zájem (Svjaščennaja metropolija Abchazija nedat.b). RPC umožnila Abcházům studovat na ruských duchovních školách (RPC MP 2006). Krok byl neoficiální, protože nebyl úplně v souladu s pravidlem nevměšování se do kanonického teritoria jiných pravoslavných církví, k jehož dodržování sama RPC vyzývala. Neoficiální pomoc abcházskému vedení nevyhovovala, vedení RPC bylo dokonce obviněno z toho, že podporuje ,zrádnou“ politiku světského vedení Ruska. ${ }^{3}$ Představitelé Abcházie chtěli, aby Alexij II. jmenoval hlavu Abcházské eparchie (fakticky to znamenalo, že APC by se stala součástí RPC) (Svjaščennaja metropolija Abchazija nedat.a; Svjaščennaja metropolija Abchazija nedat.d). S podobnou žádostí se obraceli dokonce na nového ruského prezidenta - Vladimíra Putina (Svjaščennaja metropolija Abchazija nedat.e).

Ovšem tyto žádosti RPC odmítla a na oficiální úrovni považovala Abcházii za součást kanonického teritoria gruzínské církve (RPC MP 2005a; Dbar 2013:1). Kromě toho byli představitelé RPC ochotni vystupovat v roli prostředníka v otázce navázání dialogu mezi abcházskými farnostmi a Tbilisi, aby se normalizovala církevní situace v Abcházii v souladu s církevními kánony (RPC MP 2005a). ${ }^{4} \mathrm{Na}$ začátku března 2004 se na fóru v Moskvě za pomoci vedení RPC Vissarion setkal s Iliem II. Během vyjednávání se podařilo zahájit dialog, který však neměl ohlas u veřejnosti a neměl dlouhodobých důsledků (Silantjjev 2007: 140).

Otec Vissarion ve svých vystoupeních mluvil o tom, že církevní život v Abcházii se začal rozvíjet pouze díky pomoci RPC (Aplia, Sagaň 2012). Začínají být patrné i aktivní kontakty mezi Abcházskou církví a Krasnodarskou a Majkopskou diecézí RPC (Mitrochin 2004: 520). V Majkopské diecézi byli vysvěceni Abcházci, kteří absolvovali ruské duchovní školy a pak s povolením diecéze odjeli vést bohoslužby (Dbar 2013: 2; Tjurenkov 2019). V rozvoji duchovního života v Abcházii jím měla pomoct řada ruských duchovních, kteří vedli bohoslužby v abcházských chrámech (Lučaninov 2015).

Lze předpokládat, že nesoulad mezi rétorikou RPC a její činností vưči Abcházské církvi byl viditelný i pro GPC, což si vedení RPC uvědomovalo. V roce 2003, před př́ijezdem gruzínského patriarchy Ilii II. do Moskvy, abcházské duchovní, které byli oficiálně i duchovní Majkopské a Adygejské diecéze, byli RPC antedatovaně vyřazena ze stavu (Dbar 2013: 2). Ale tento krok neznamenal, že RPC přestane zasahovat do církevního dění v Abcházii.

V roce 2005 RPC zasahuje do konfliktu mezi Apliou a vyřazenými duchovními - Andrejem Amparem a Dorofejem Dbarem, kteří fakticky spravovali klášter v Novém Athosu ${ }^{5}$ (Dbar 2013: 2). V tomto konfliktu RPC podpořila Apliu a vzhledem k tomu, že Ampar a Dbar patřili de facto do Majkopské diecéze, přestala jim umožňovat činnost až do vyřešení problému (i když oficiálně jim pokračovat ve službě nezakázala) (Kostanenko 2012).

V roce 2007 se v Abcházii konala duchovní akce s požehnáním Alexije II., v jejímž rámci bylo abcházským dětem předáno 2,5 tuny duchovně mravní literatury a abcházským farnos-

\footnotetext{
${ }^{3}$ Za zrádnou byla považována blokáda Abcházie, která byla vyhlášena Jelcinem na žádost Ševarnadzeho a fakticky byla ukončena v roce 1999. Blokáda spočívala v tom, že muži od 16 do 60 let se nemohli dostat do Ruska přes hraniční přechod Psou a veškeré dodávky potravin a obchod byly zakázány. Ovšem fakticky Rusko přestalo dodržovat politiku sankcí po nástupu Putina (Lučaninov 2015).

${ }^{4}$ Celkem lze říci, že po nástupu Putina a změně ruského vztahu vůči Abcházii na neoficiální úrovni se mění i církevní situace. Ruské ministerstvo zahraničí tvrdilo, že Abcházie je součástí Gruzie a může být přijata do Ruska pouze se souhlasem Gruzie. Ovšem Rusko přijalo v roce 2002 zákon o občanství, který vyvolal značné znepokojení gruzínské strany, protože umožňoval zrychlené vydávání ruských pasů obyvatelům Abcházie a Jižní Osetie (Newsru.com 2009).

${ }^{5}$ Vissarion a zmínění duchovní měli odlišný pohled na způsob řízení klášterů a na jurisdikci APC. Vissarion trval na tom, že církev má být součástí RPC, mladí duchovní ovšem mluvili o tom, že má být nezávislá, což znamenalo, že ženatý Vissarion v čele nezávislé církve být nemůže (Muchanov 2016: 130-132; Silant̉jev 2007: 139-140).
} 
tem bylo předáno 1000 výtisků evangelia v abcházštině. Evangelium bylo přeloženo vydavatelskou radou RPC za podpory společnosti Ruské železnice, administrace prezidenta, administrace Krasnodarského kraje a řady jiných organizací (RPC MP 2007b). Kromě toho RPC věnovala značnou pozornost i opravě kláštera v Novém Athosu, na které se podílela ruská strana ${ }^{6}$ (RPC MP 2008a; RPC MP 2008b). V čele pravoslavné jihoosetské komunity v 90. letech stanul Alexandr Puchate (v jiných zdrojích Puchajev), který se po válce obrátil na RPC s žádostí o připojení (nepodařilo se dohledat informace, zda se na tom podílelo i světské vedení Jižní Osetie). Stejně jako v př́padě Abcházie, RPC žádost odmítla a připomněla, že se nesmí vměšovat do církevních záležitostí na kanonickém území GPC ${ }^{7}$ (Regnum 2005).

Puchate se na rozdíl od představitelů Abcházie s touto situací nesmíril a pokračoval v hledání církevní jurisdikce, která by byla ochotná připojit jihoosetskou komunitu. Obrátil se na Ruskou pravoslavnou církev v zahraničí (RPCZ), která žádost schválila. Připojení k RPCZ vedlo k posílení pravoslavné komunity na území Jižní Osetie (Mitrochin 2004: 520-521). Když v RPCZ v roce 2001 došlo k schizmatu, Puchate se obrátil na schizmatickou Řeckou pravoslavnou starostylní církev, která jihoosetskou církev v roce 2003 přijala a přetvořila na Pravoslavnou diecézi Jižní Osetie Alanie (?onroy 2015: 633). Ve stejném roce byl podepsán konkordát mezi vedením Jižní Osetie a vedením diecéze (Regnum 2005). Ovšem již dříve bylo v Ústavě Jižní Osetie přijaté v roce 2001 v článku 33 uvedeno, že pravoslaví a tradiční osetské náboženství jsou jedním ze základů národního sebeuvědomění (Prezident Južnoj Osetii 2012).

Do srpna roku 2008 lze na webu RPC najít 7 zmínek, které se týkají vývoje církevního života pouze v Jižní Osetii (bez zmínek o Abcházii). ${ }^{8}$ Dvě z nich jsou věnované církevní prř́slušnosti Jižní Osetie, dvě návštěvě Ilii II. a ostatní jsou věnovány činnosti metropolity Stavropolského a Vladikavkazského Feofana. Aktivita Feofana v Jižní Osetii byla v rozporu s oficiální pozicí RPC a ve velké míře přispěla $\mathrm{k}$ tomu, že představitelé jihoosetského světského i církevního vedení uváděli, že RPC nejenže žádným způsobem nepodporovala vývoj církevního života v Jižní Osetii, ale zrazovala obyvatelstvo Jižní Osetie (Amelina 2005; Sekritariat Alanskoj eparchii 2008; Lunkin 2008). Feofan se v roce 2005 zúčastnil vojenské přehlídky věnované patnáctiletému výročí nezávislosti Jižní Osetie a odmítl na ní komunikovat s představiteli Alanské církve, protože, dle jeho názoru, nezastupují osetský lid. ${ }^{9}$ Přiznal ale, že se občané Jižní Osetie zúčastňují církevních obřadů na území Severní Osetie a nevidí v tom porušení práv GPC. S tím nesouhlasila GPC a Ilia II. poslal Alexiji II. dopis, ve kterém patriarchu upozornil, že tento krok porušuje církevní pravidla a práva GPC $^{10}$ (Interfax Religija 2005).

Vzhledem k vysoké pozici Feofana a k tomu, že neexistuje dostupný dokument RPC, který by odsuzoval kroky jejího biskupa, se zdá, že není možné vnímat názor Feofana pouze jako názor jednotlivce, který je v úplném rozporu s názorem instituce, kterou reprezentuje. Feofan se navíc v roce 2006 stal členem komise pro národnostní otázky a mezikonfesionální vztahy Občanské komory RF (RPC MP 2007c).

Postoj představitelů RPC ohledně „státnosti“ Abcházie se skoro neliší od jejich postoje v př́ípadě Jižní Osetie. Zmínky o Abcházii a Jižní Osetii jako o neuznaných oblastech se poprvé objevují na webu RPC v roce 2005 a až do roku 2008 byly oba státy jedinými státními útvary, před jejichž názvem se ve většině případi̊ vyskytovalo slovo „neuznaný“11 (například RPC MP 2005b; RPC

\footnotetext{
${ }^{6}$ Pkhaladze (2012: 169) dokonce uvádí, že obnovení kláštera v Novém Athosu financovalo ruské vedení.

${ }^{7}$ Dle dostupné informace, představitelé RPC v tomto případě neprojevují zájem o roli mediátora mezi GPC a jihoosetinskou církví.

${ }^{8} \mathrm{Na}$ webu RPC za stejné období se podařilo najít 17 relevantních zmínek o Abcházii, o Jižní Osetii a Abcházii ve stejném dokumentu existuje pouze 5 zmínek.

${ }^{9}$ Dle jihoosetinské strany Feofan tvrdil, že v Jižní Osetii je právě on vlastníkem všech farností a představitelé Alanského biskupství nejsou nikým (Osetinskoje radio i televidenije 2005a).

${ }^{10} \mathrm{~V}$ otevřeném dopisu věřících Jižní Osetie je interpretace Feofanovy činnosti opačná. Jeho chování je hodnoceno jako prospěšné a podporující GPC (Osetinskoje radio i televidenije 2005b).
} 
MP 2005?; RPC MP 2008c). Dle webu RPC, se její vedení nesetkávalo se světskými představiteli a neposílalo dopisy jihoosetskému a abcházskému vedení, a tedy ani negratulovalo ke zvolení prezidenta, oslavám nezávislosti apod., což je obvyklá praxe vůči uznaným státům. Nejsou také dostupné materiály, dle kterých by bylo možné soudit, že vedení RPC vnímá Abcházii a Jižní Osetii jako součást Ruska. Ovšem v rámci RPC se vyskytovaly i odlišné pozice. Jako př́klad lze uvést pozici již zmíněného metropolity Stavropolského a Vladikavkazského, Feofana, který na pozvání „prezidenta a národa Jižní Osetie“ přijel na oslavy 15letého výročí nezávislosti Jižní Osetie a prohlásil, že problémy regionu spočívají v tom, že Jihooseti a Severooseti jsou jediným národem, který nelze dělit (RPC MP 2005b; RPC MP 2005d). Vedení Abcházie se v Rusku setkávalo s biskupem Nižního Novgorodu, který se ke statusu Abcházie nevyjadřoval, ovšem ve zprávě ze setkání s prezidentem Abcházie je prezentován jako vysoce postavený státní činitel (Nižegorodskaja mitropolija 2007). Proti tomu stojí v kontrastu projev Ilii II., ve kterém se zmiňuje o tom, že RPC je zastáncem myšlenky o nedotknutelnosti územní celistvosti Gruzie (RPC MP 2008d).

Státní představitelé církevní situaci v obou oblastech nehodnotili, ovšem jejich politická pozice vưči oblastem byla podobná pozici RPC vůči Abcházii a Jižní Osetii. V roce 1997 se Rusko neúspěšně pokoušelo být prostředníkem mezi Abcházií a Gruzií (Makaryčev 2016). S nástupem Putina se situace změnila. Ruské světské vedení tvrdilo, že Abcházie a Jižní Osetie jsou součástí Gruzie. Ovšem Rusko přijalo v roce 2002 zákon o občanství, který vyvolal značné znepokojení gruzínské strany, protože umožňoval zrychlené vydávání ruských pasů obyvatelům Abcházie a Jižní Osetie (Newsru.com 2009). Členové Státní Dumy, moskevské vlády a vedení některých jiných ruských oblastí byli př́tomni na oslavách nezávislosti Jižní Osetie (RPC MP 2005c). Kromě toho, ruská strana podporovala tyto oblasti ekonomicky a vojensky - existoval plán, vytvořený generálním štábem a schválený Putinem, podle kterého probíhala i př́íprava jihoosetských domobranců (Kremlin 2012).

\section{Vývoj vztahů RPC vůči Jižní Osetii a Abcházii po roce 2008}

Během války roku 2008 a po ní se ukázalo, že interpretace události ze strany ruského světského vedení je dost podobná pozici představitelů RPC. Alexij II. vyzval vedení Ruska, aby se vrátilo k formátu jednání a nesnažil se politicky hodnotit vojenský zásah Ruska (RPC MP 2008e). Ovšem jiní vysoce postavení církevní činitelé viníky aktivně hledali a stát ve válce podporovali. Již zmíněný metropolita Feofan byl dokonce jedním z členů ruské delegace v Berlíně, kde spolu s řadou prokremelských činitelů vysvětloval německým politikům a novinářům, že humanitární katastrofa, ke které došlo v Jižní Osetii je výsledkem gruzínské agrese (RPC MP 2008f). Později Feofan seznámil ministra zahraničních věci Francie s „rozmachem tragédie zpưsobené zrádným útokem gruzínských ozbrojených sil na mírová města a obce republiky Jižní Osetie“ (Russkaja linija 2008). Podobnou pozici zastával i metropolita (dnešní patriarcha) Kirill, který v rámci svého programu „Slovo pastýře“ mluvil o agresi ze strany Gruzie (Gundjaev 2008). Objevuje se i názor, podobný státnímu hledisku (Kremlin 2008a; Vernickij 2008; MID 2008a), o nutnosti ochránit obyvatelstvo před agresí ze strany Gruzie (Bykova 2008) a tvrzení o genocidě jihoosetského obyvatelstva (Russkaja linija 2008).

Stejně jako ruští státní činitelé, kteří viděli za válkou z roku 2008 vliv USA (Vernickij 2008; MID 2008a; Kremlin 2008b), představitelé církve uváděli, že Spojené státy režírovaly agresi ze strany Gruzie vůči Jižní Osetii (Bykova 2008). Za viníka stát a církev označovaly i západní média, která se snažila pomlouvat Rusko (OVCS 2008). Církevní představitelé, stejně jako ruské MZV, poukazovali na dvojí standardy západních medií, které považovali za nepřijatelné vzhledem

\footnotetext{
${ }^{11} \mathrm{~V}$ jiných případech se slovo „neuznány“ používalo vůči Ukrajinské pravoslavné církvi Kijevského patriarchátu a Makedonské pravoslavné církvi.
} 
k tomu, že „zbavuji občanskou společnost v Evropě a Americe pravdivých informaci“ (RPC MP 2008g). Nesprávně dle nich vykreslovala situaci v Jižní Osetii i gruzínská média narozdíl od pravdivých informací v ruských médiích (Semjonov 2008).

Analýza oficiálního webu RPC ukazuje, že po roce 2008 se ze strany církve objevují i první zmínky o Abcházií a Jižní Osetii jako o státních útvarech (slovo „neuznaný“ úplně zmizelo z rétoriky představitelů RPC vůči Abcházii a Jižní Osetii). Církevní činitelé mluvili o tom, že změna státních hranic, která nastala $\mathrm{v}$ př́padě Abcházie a Jižní Osetie, nemůže mít vliv na změnu církevních hranic. Ovšem lze se setkat nejen s nepř́mým uznáním „státnosti“ Jižní Osetie a Abcházie, ale i s přímými připomínkami (napřr. IA Res 2011). Metropolita Kirill, když se stal patriarchou, pogratuloval Jižní Osetii k dvacetiletému výročí schválení deklarace o suverenitě Jižní Osetie. Ve svém dopisu zdůraznil, že „[v] uplynulých letech vedení a národy státu musely projít nelehkou cestu státního utvárení, sociálního a ekonomického rozvoje" (RPC MP 2010a). Slovo „stát“ je používáno i v blahopřání prezidentu Bibilovi ke zvolení (RPC MP 2017b). S Abcházií byla situace stejná, např́ílad ve svém blahopřání Bagapšovi nebo Ankvabovi ke zvolení do funkce prezidenta Kirill používá slovo „stát“ (RPC MP 2010b; RPC MP 2011). Kromě různých telegramů se vedení RPC začíná i osobně setkávat s abcházskými i jihoosetskými politickými činiteli (RPC MP 2019).

Nejsou veřejně přístupná hodnocení církevní přríslušnosti Abcházie a Jižní Osetie ze strany ruského světského vedení. Ale je patrné, že RPC zřejmě nemohla uznat církevní nezávislost ani vzít Abcházii a Jižní Osetii pod svou jurisdikci (Allenova 2011), protože měla řadu problémů s existencí schizmatických církví na svém kanonickém teritoriu a spoléhala na podporu GPC (Allenova 2011; Hoch, Khundadze 2017: 18; Minesashvili 2018: 50). Navíc by podobný krok mohl výrazně zhoršit i vztahy RPC s ostatními pravoslavnými církvemi, což by nevyhovovalo RPC, která usiluje o velký vliv v pravoslavném světě (Minesashvili 2018: 50).

Tento postoj je patrný i v projevech církevních činitelů, kteří uznávali, že území obou republik je nadále součástí gruzínské církve (RPC MP 2009; Semjonov 2008). Ovšem rétorika RPC ohledně církevních záležitostí začíná mít i nové prvky. Objevují se zmínky o tom, že striktní dodržování pravidla kanonického území ve vztahu k Abcházii a Jižní Osetii není možné (Semjonov 2008) nebo že GPC fakticky nespravuje tyto oblasti. Někteří církevní činitelé jako možné řešení problému navrhovali, aby GPC dočasně předala řízení abcházské a jihoosetské církví RPC (Interfax Religija 2009). Kanál „Spas“, jehož zřizovatelem je RPC, vyhlásil soutěž na projekty chrámů pro Abcházii a Jižní Osetii. „Na území těchto států žije velký počet ruských (pravděpodobně se použivá ve smyslu rossijskij - pozn. autora) pravoslavných obyvatel, v blízké budoucnosti zde budou umístěny stálé posádky ruské armády. Proto je vznik chrámu RPC v každé z republik celkem logický “ (RPC MP 2008h). Podle pravoslavných kánonů by ale RPC měla začít o něčem podobném mluvit pouze se svolením gruzínské církve, které zřejmě neměla. Celkově se RPC snažila upevňovat svou pozici v regionu i prostřednictvím udržování dobrých vztahů s vedením Jižní Osetie a Abcházie a prostřednictvím změny diecézních hranic na severním Kavkazu (Curanoviće 2012: 175-176).

Bez ohledu na uvedenou informaci, nelze říct, že vztah k církevním strukturám v Abcházii a Jižní Osetii byl stejný. Představitelé RPC označovali církev na území Jižní Osetie za schizmatickou (Semjonov 2008; Vesti 2009) a její představitele - za samozvance (RPC MP 2009). Existence Alanské dieceze byla považována pro Rusko za velký problém, protože byla pobočkou církve, jejíž historická činnost „,je ve vztahu k Rusku směřována na oslabování ruské pravoslavné církve“. Z uvedeného vyplývá, že situace, kdy ruští vojáci bojovali za Jižní Osetii, jejíž církev usilovala o narušení jednoty RPC, nebyla správná a vyžadovala okamžité řešení se světskými 
představiteli Jižní Osetie ${ }^{12}$ (Semjonov 2008; Vesti 2009). Světští (a církevní) představitelé Jižní Osetie nebyli ochotni řešit existující problém s RPC, protože jednak existenci vlastní církve jako součásti Řecké pravoslavné starostylní církve nepovažovali za problém, jednak nadále obviňovali RPC z toho, že nekomunikuje s představiteli jihoosetské církve a že se nechtěla zamyslet nad připojením jejich církve k RPC v důsledku existence silné progruzínské lobby (Lunkin 2008; Kulumbekov 2011). S otevřeným dopisem se na ruského prezidenta obrátili dokonce představitelé mládežnických organizací Jižní Osetie a žádali o ochranu před RPC (IA Alanijainform 2010). A světští představitelé Jižní Osetie začali uvádět, že alanská diecéze nikdy nepatřila nejen gruzínské, ale ani ruské pravoslavné církvi (Chubajeva 2010).

V roce 2015 se objevila informace, že Rusko začíná budovat chrám RPC v centru Cchninvali, přičemž volbou místa a otázkami budování chrámu se původně zabýval duchovní RPC, který je zároveň občanem Jižní Osetie, a založil nadaci pro obrodu pravoslaví v Jižní Osetii (Malcev 2015; Gabarajeva 2016).

Poté, co do čela Jižní Osetie nastoupil A. Bibilov, který považuje za svůj cíl připojení Jižní Osetie k Rusku, se náboženská situace v Jižní Osetii změnila. Je patrné, že existuje zájem na vyvolání nového kola vyjednávání o možnosti připojení jihoosetské církve k RPC. Bibilov se častěji než předchozí státní činitelé obrací na duchovní RPC, je přítomen na pravoslavných svátcích v ruském chrámu a fakticky alanskou diecézi ignoruje (např. Kelechsajeva 2018) (navíc se objevila informace, že biskup alanské diecéze přišel o jihoosetský pas (Gumekuchov 2018).

S Abcházií byla situace obtížnější. Poté, co byl APC abcházským vedením navrácen veškerý majetek, který byl sebrán během sovětského období, z něhož nejdůležitějším a nejpřínosnějším byl klášter v Novém Athosu, spravovaný „po zpovědi a přiznání chyb“ Andrejem Amparem (Muchanov 2016: 131), začínají být stále zřejmější staré rozpory mezi Vissarionem a Amparem. V jejich důsledku RPC pod záminkou opakovaných žádostí ze strany Vissariona poslala do čela kláštera v Novém Athosu igumena Efrema (Kostanenko 2012; Lučaninov 2015).

Informaci o př́ijezdu ruského duchovního, která vyvolala znepokojení ze strany GPC, pak RPC popírala (Interfax Religija 2011). Nesouhlas s krokem RPC vyjádřil i Andrej Ampar (Muchanov 2016: 131). Ten se zřejmě obával, že příjezd ruského duchovního, který se dobře znal s Vissarionem (Lučaninov 2015) znamená pouze to, že Vissarion se snaží veškeré příjmy soustředit do svých rukou, a proto ihned po příjezdu Efremy svolal církevně občanské jednání, které se rozhodlo vytvořit Svatou metropolii Abcházie s cílem dosažení úplné nezávislosti a autokefálie (Pkhaladze 2012: 168). V čele nové církve stanul Dorofej Dbar, který se po zákazu služby ze strany RPC obrátil na řeckou církev, získal status archimandrity a je oficiálním duchovním řecké pravoslavné církve (Hoch, Khundadze 2017: 18).

Schizma v abcházském náboženském životě, v neposlední řadě kvůli činnosti RPC, mělo vliv i na politickou situaci v Abcházii. Politickým činitelům Abcházie se líbila myšlenka existence nezávislé církve (Hoch, Kopeček, Baar 2017: 335), protože nezávislost církve vnímali jako krok k dosažení státní nezávislosti (Gamcemlidze 2016), a proto Svatou metropolii Abcházie podporovali (Pereverzev 2011; Regnum 2011). Ruská strana ovšem upozornila abcházské politické činitele, že podpora Svaté metropolii Abcházie bude mít pro Abcházii vážné důsledky (Russkaja linija 2011). Kromě toho bylo oběma duchovním - Amparovi a Dbarovi ze strany RPC okamžitě zakázáno sloužit a Krasnodarská diecéze striktně doporučila, aby Rusové nejezdili do kláštera v Novém Athosu a nemodlili se tam, nebot klášter je hlavním sídlem schizmatické skupiny (Kostanenko 2012). Takové doporučení bylo předáno do všech farností RPC a je platné dodnes. Ovšem doporučení dnes není reálně dodržováno a Nový Athos patří mezi ruskými turisty k nejoblíbe-

\footnotetext{
${ }^{12}$ Není ovšem jasné, jak ve skutečnosti RPC chtěla problém s církevní přislušnosti obou oblasti řešit a jak existence Alanské diecéze porušovala práva RPC, jestliže bereme v potaz fakt, že území Jižní Osetie a Abcházie není kanonickým územím RPC.
} 
nějším fungujícím klášterům. Abchazská pravoslavná církev a Svatá metropolii Abcházie dnes aktivně soupeří, obě strany se obviňují navzájem a jsou podporovány třetími stranami.

RPC i nadále podporuje Vissariona a jím vedenou Abcházskou pravoslavnou církev. Abcházská církev ze své strany podporuje RPC v konfliktu s Konstantinopolským patriarchou a na jejích webových stránkách (včetně úvodní) je odkaz na webové stránky RPC a weby s ní spojené (pro vice informací viz http://aiasha.ru/).

Svatá metropolie Abcházie je podporována ze strany řecké pravoslavné církve (Hoch, Khundadze 2017: 17; Gamcemlidze 2016), kontakty s RPC fakticky nemá, ale zúčastňuje se akcí, pořádaných ruskou stranou (Svjaščennaja mitropolija Abchazija 2018). Kromě toho, Dbar za podpory abcházského prezidenta napsal ruskému patriarchovi dopis s prosbou o zrušení zákazu vykonávat bohoslužby (Svjaščennaja metropolija Abchazija 2019). Činnost RPC je očividně vnímána i GPC, která s tím však nic zásadního udělat nemůže (Hoch, Khundadze 2017: 18).

\section{Závěr}

RPC je dnes důležitým aktérem v ruské politice. Jestliže se během 90 . let RPC snažila upevňovat svou pozici na svém kanonickém území, pak po nástupu Putina se RPC snaží zasahovat i mimo své kanonické území. Předložený text se pokusil oponovat názorům, že se pozice RPC vůči Abcházii a Jižní Osetii lišila od politiky ruského státu.

Analýza ukázala, že války mezi Gruzií a Abcházií a Jižní Osetií na začátku 90. let vedly k výraznému odporu vůči všemu gruzínskému ze strany obyvatel Abcházie a Jižní Osetie. Vedení Abcházie a Jižní Osetie vidělo v nezávislosti na gruzínské církvi jeden z nástrojů, jak prokázat celkovou nezávislost na Gruzii, což přetvářelo otázku církevní na otázku politickou, a tím pádem znemožňovalo faktickou participaci GPC na církevním životě v Abcházii a Jižní Osetii. Představitelé obou de facto států hledali nejen politickou, ale i náboženskou podporu u představitelů Ruska a RPC. Po nástupu prezidenta Putina do čela Ruské federace začíná být patrná blahosklonná pozice Ruska vůči těmto de facto státům. I když na oficiální státní úrovni se o nich mluvilo jako o součásti Gruzie, na neoficiální úrovni byly tyto oblasti podporovány, což vyvolávalo značné znepokojení představitelů Gruzie. Názor představitelů RPC ohledně otázky „státnosti“ Jižní Osetie a Abcházie byl jednotný - do roku 2008 byly označovány za neuznané (státní představitelé podobné označení skoro nepoužívali).

V dostupných projevech nejvyšších ruských světských představitelů se nepodařilo najít hodnocení církevní příslušnosti obou de facto států. Výzkum ovšem ukázal, že lze najít podobné rysy mezi politickou pozicí ruského světského vedení vůči Abcházii a Jižní Osetii a pozicí RPC ohledně církevní příslušnosti Abcházie a Jižní Osetie. Vedení RPC během celého období mluvilo o právu GPC na Abcházii a Jižní Osetii.

Neoficiální postoj byl ovšem jiný a analýza ukázala, že postoj vůči Jižní Osetii se lišil od postoje vůči Abcházii. Do náboženských záležitostí v Jižní Osetii představitelé RPC téměř nezasahovali (s výjimkou metropolity Feofana). V Abcházii si ale RPC dovolila zasahovat do církevních záležitostí, komunikovala a vysvěcovala abcházské náboženské činitele. Činnost RPC vyvolávala značné znepokojení ze strany GPC.

Během války v roce 2008 také nelze mluvit o odlišném postoji mezi představiteli ruského světského a církevního vedení. RPC, stejně jako ruský stát, se po roce 2008 k Abcházii a Jižní Osetii začíná chovat jako ke státům.

Po uznání Abcházie a Jižní Osetie ze strany Ruska, představitelé církve i nadále mluví o církvích Abcházie a Jižní Osetie jako o součásti GPC, ovšem začínají uznávat, že GPC tam nemůže působit a že je potřeba de facto státům pomoci. Podobná, i když často neoficiální „pomoc“ 
nezřídka vede k znepokojení místních obyvatel. Ukazuje se, že RPC do církevního života Abcházie a Jižní Osetie výrazně zasahuje.

Analýza, která byla provedena v rámci předloženého textu, neumožňuje konstatovat, že se pozice RPC a ruského státu liší. Jediný bod, který se liší v církevní a politické rovině, spočivá v uznání církevní příslušnosti Abcházie a Jižní Osetie. Ovšem vzhledem k tomu, že se ruští světští činitelé k církevní příslušnosti Abcházie a Jižní Osetie nevyjadřovali, nelze mluvit o nějakém nesouladu mezi pozicemi představitelů RPC a ruského světského vedení. Zároveň to umožňuje hovořit o značně podobné pozici ruského státu a církve vůči Abcházii a Jižní Osetii.

\section{Financování}

Článek byl zpracován v rámci Institucionální podpory na dlouhodobý koncepční rozvoj výzkumné organizace 2019 Katedry politologie a mezinárodních vztahů FF ZČU v Plzni.

\section{Bibliografie}

Agababajan, A. 2016. „,Vo čto my věrimi vozroždenije ,tradicionnoj religii“ v postvojennoj Abchazii." Gosudarstvo, religija, cerkov'v Rossii i za rubežom 34 (2): 67-91, https://doi.org/10.22394/2073-72032016-34-2-331-356.

Allenova, O. 2011. „Teologičeskaja vojna." [online] Kommersant, 20. 6. 2011 [cit. 1. 1. 2019]. Dostupné z: http://kommersant.ru/doc/1659846.

Amelina, J. 2005. „Nepriznannoje pravoslavije.“ [online] Russkij žurnal, 30. 3. 2005 [cit. 13. 2. 2018]. Dostupné z: http://old.russ.ru/culture/20050330_amel-pr.html.

Aplia, V., A. Sagaň. 2012. „Abchazskije raskol'niki: oni vyšli ot nas, no ne byli našimi. . “ “ [online] Pravmir, 2. 7. 2012 [cit. 13. 2. 2018]. Dostupné z: http://www.pravmir.ru/abxazskie-raskolniki-oni-vyshli-ot-nas/.

Avanesova, M., V. Naxera. 2018. „ZZa ochranu křestanstvį́: postoje ruské pravoslavné církve vưči Západu a její místo v zahraniční politice Ruské federace." Mezinárodni vztahy 53 (2): 20-42, https://doi.org/ $10.32422 / \mathrm{mv} .1554$.

Bezborodov, M. 2010. „Meždunarodnaja dejatjelnost russkoj pravoslavnoj cerkvi: vněšnepolitičeskije pozicii i sotrudničestvo s gosudarstvom." Socium $i$ vlast' 27 (3): 84-89.

Bykova, N. 2008. „Archijepiskop Feofan: My živem v drugoj strane." [online] Stavropolskaja Pravda, 17. 10. 2008 [cit. 13. 2. 2018]. Dostupné z: http://www.stapravda.ru/20081017/Arhiepiskop_Feofan_ My_zhivem_v_drugoj_strane_33625.html.

Conroy, K. 2015. „Semi-Recognized States and Ambiguous Churches: The Orthodox Church in South Ossetia and Abkhazia." Journal of Church and State 57 (4): 621-639, https://doi.org/10.1093/jcs/csu029.

Curanović, A. 2012. The Religious Factor in Russia's Foreign Policy. London: Routledge.

Čapnin, S. 2018. Cerkovnoje vozrožděnije. Itogi. Moskva: Eksmo.

Dbar, D. 2006. Kratkij očerk istorii Abchazskoj Pravoslavnoj Cerkvi. Novyj Afon: Stratofil.

Dbar, D. 2013. „Prišla očerednaja žaloba.“ Christianskaja Abchazija 11 (79): 1, 2, 9.

Gabarajeva, E. 2016. „Južnaja Osetija - christianskaja respublika i stroitelstvo pravoslavnoj cerkvu, vpolne jestestvenno." [online] IA Res, 15. 4. 2016 [cit. 1. 1. 2019]. Dostupné z: http://cominf.org/node/ 1166508229.

Gamcemlidze, D. 2016. „Kak Gruzinskaja cerkov’ vybirajet meždu Moskvoj i Brusselem. “ [online] Carnegie, 21. 11. 2016 [cit. 1. 12. 2017]. Dostupné z: https://carnegie.ru/commentary/66206.

Grigorjan, V. 2006. „My sdelali svoj vybor.“ [online] Gazeta Eskom-Věra, 28. 2. 2006 [cit. 11. 5. 2018]. Dostupné z: http://rusvera.mrezha.ru/510/5.htm.

Gumekuchov, M. 2018. „Vsjo delajetsja dlja togo, čtoby uničtožit Alasnskuju eparchiju." [online] Echo Kavkaza, 18. 4. 2018 [cit. 1. 1. 2019]. Dostupné z: https://www.ekhokavkaza.com/a/29175498.html.

Gundjaev, V. 2008. „Smolenskiy mitropolit Kirill osudil bojevyje dejstvija v Južnoj Osetii i Gruzii. “ [online] Echo Moskvy, 16. 8. 2008 [cit. 13. 2. 2018]. Dostupné z: http://echo.msk.ru/programs/beseda/534401echo/.

Hoch, T., T.Khundadze. 2017. „Pravoslavné církve a transformace gruzínsko-abcházského konfliktu.“ Mezinárodní vatahy 52 (3): 7-22. 
Hoch, T., V. Kopeček, V. Baar. 2017. „Civil Society and Conflict Transformation in De Facto States." Problems of Post-Communism 64 (6): 329-341, https://doi.org/10.1080/09668136.2016.1147528.

Hudson, V. 2018. „The Ukrainian Orthodox Church of the Moscow Patriarchate as a Potential 'Tool' of Russian Soft Power in the Wake of Ukraine's 2013 Euromaidan. " Europe-Asia Studies 70 (9): 13551380, https://doi.org/10.1080/09668136.2018.1536780.

Chedia, B. 2009. „Rol' gruzinskoj Pravoslavnoj cerkvi v sovremennych političeskich processach Gruzii.“ Centralnaja Azija i Kavkaz 64-65 (4-5): 191-198.

Chubajeva, S. 2010. „Zajavlenije upolnomočennogo po dělam religii Južnoj Osetii." [online] Portal Credo.ru, 24. 1. 2010 [cit. 1. 1. 2019]. Dostupné z: https://credo.press/109851/.

IA Alanijainform. 2010. „Pravoslavnyje Južnoj Osetii obraščajutsja k Dmitriju Medvedevu s pros’boj zaščitit' ich ot duchovnogo istreblenija. " [online] IA Alanijainform, 22. 1. 2010 [cit. 1. 12. 2017]. Dostupné z: http://osinform.org/19178-pravoslavnye-yuzhnoj-osetii-obrashhayutsya-k.html.

IA Alanijainform. 2011. „Chubajeva: ,Ilija II. predstanjet pered Bogom i, ja nadejus, čto Bog budet spravedliv6" [online] IA Alanijainform, 1. 4. 2011 [cit. 1. 12. 2017]. Dostupné z: http://osinform.org/ 28810-hubaeva-ilya-ii-predstanet-pered-bogom-i-ya-nadeyus-chto-bog-budet-spravedliv.html.

IA Res. 2011. „Archijepiskop Vladikavkazskij i Machačkalinskij Zosima pozdravil Eduarda Kokojty s 21-j godovščinoj provozglashenija Respubliki Južnaja Osetija." [online] IA Res, 23. 9. 2011 [cit. 1. 1. 2019]. Dostupné z: http://cominf.org/node/1166489422.

Interfax Religija. 2005. „Gruzinskij patriarch napravil pismo protesta Alexiju II." [online] Interfax Religija, 21. 9. 2005 [cit. 13. 2. 2018]. Dostupné z: http://www.interfax-religion.ru/gry/?act=news\&div=6296.

Interfax Religija. 2009. „Optimal'noje rešenije problemy Abchazskoj jeparchii - peredat' jejo vo vremennoje upravlenije Moskovskomu patriarchu." [online] Interfax Religija, 16. 9. 2009 [cit. 1. 1. 2019]. Dostupné z: http://www.interfax-religion.ru/?act=interview\&div=232.

Interfax Religija. 2011. „Patriarch Kirill ne naznačal svojego predstavitelja nastojatelem monastyrja v Abchazii, zajavljaut v Tbilisi." [online] Interfax Religija, 5. 4. 2011 [cit. 1. 1. 2017]. Dostupné z: http://www.interfax-religion.ru/gry/?act=news\&div $=40194$.

Južnaja Osetija segodnja. 2018. „Sonja Chubajeva: Alanskaja eparchija nikogda ne vchodika v sostav GPC." [online] Južnaja Osetija segodnja, 16. 1. 2018 [cit. 1. 1. 2019]. Dostupné z: http://southossetia.info/sonya-xubaeva-alanskaya-eparxiyat-nikogda-ne-vxodila-v-sostav-gpc/.

Kelechsajeva, I. 2018. „Prezident vybral sebe druguju cerkov'“ [online] Echo Kavkaza, 10. 4.2018 [cit. 1. 1. 2019]. Dostupné z: https://www.ekhokavkaza.com/a/29157060.html.

Kostanenko, L. 2012. „Ostorožno: raskol v Novo-Afonskom Simono-Kananitskom monastyre." [online] Pravoslavnaja Kubaň, 28. 12. 2012 [cit. 1. 12. 2017]. Dostupné z: http://pravkuban.ru/main/ 1158346353-ostorozhno-raskol-v-novo-afonskom-simono-kananitskom-monastyre.html.

Kremlin. 2008a. „Stenografičeskij otčjot o vstreče s učastnikami meždunarodnogo kluba ,Valday“" [online] Kremlin, 12. 9. 2008 [cit. 13. 2. 2018]. Dostupné z: http://www.kremlin.ru/events/president/ transcripts $/ 1383$.

Kremlin. 2008b. „Poslanije Federal'nomu Sobraniju Rossijskoj Federacii.“ [online] Kremlin, 5. 11. 2008 [cit. 13. 2. 2018]. Dostupné z: http://www.kremlin.ru/events/president/transcripts/1968.

Krutinskaja, A. 2008. „Alexij II rešajet sudbu Abchazii i Južnoj Osetii.“ [online] Infox, 6. 11. 2008 [cit. 13.1. 2019]. Dostupné z: https://www.infox.ru/news/38/social/society/2138-aleksij-ii-resaet-sudbu-abhazii-iuznoj-osetii.

Krylov, A. 1999. „Abchazija: religioznaja situacija v nepriznannom gosudarstve. “ Vestnik Evrazii 4 (1-2): 143-162.

Kulumbekov, R. 2011. „Alanskaja jeparchija - simvol gosudarstvennosti Južnoj Osetii." [online] Novosti Jižnoj Osetii, 26. 1. 2011 [cit. 1. 1. 2019]. Dostupné z: http://osinform.org/27471-alanskaya-eparhiyasimvol-gosudarstvennosti-yuzhnoy-osetii.html.

Leustean, L. N. 2014. Eastern Christianity and politics in the twenty-first century. London, New York: Routledge.

Lučaninov, A. 2015. „Krestnyj otec Abchazskoj cerkvi.“ [online] NG Religija, 2. 12. 2015 [cit. 1. 1. 2017]. Dostupné z: http://www.ng.ru/ng_religii/2015-12-02/7_abhazia.html.

Lunkin, R. 2008. „Intervju: Glava Cerkvi Južnoj Osetii Episkop Alanskij Georgij (Puchate) o ,machrovom nacionalizmě Gruzinskoj patriarchii i ,predatelstve' Moskvy." [online] Portal - Credo.ru, 25. 9. 2008 [cit. 1. 1. 2019]. Dostupné z: https://credo.press/96767/. 
Lunkin, R. 2018. „Cerkov' i vněšnjaja politika: ot ,russkogo mira' k globalizacii." Naučnyje vedomocti Belgorodskogo universitěta 45 (1): 165-175, https://doi.org/10.18413/2075-4458-2018-45-1-165-175.

Makaryčev, A. 2016. „Predely rossijskoj myagkoj silj v Gruzii.“ [online] Rossija v global'noj politikě, 10. 05. 2016 [cit. 1. 12. 2017]. Dostupné z: http://www.globalaffairs.ru/PONARS-Eurasia/Predely-rossiiskoimyagkoi-sily-v-Gruzii-18158.

Malcev, V. 2015. „Moskovskij chram dlja Chinvala.“ [online] NG Religija, 15. 07. 2015, [cit. 1. 1. 2019]. Dostupné z: http://www.ng.ru/ng_religii/2015-07-15/4_osetia.html.

MID. 2008a. „Lavrov: v Abchazii i Južnoj Osetii sozdajutsja vojennyje bazy." [online] Ministerstvo inostrannych děl, 18. 9. 2008 [cit. 13. 2. 2018]. Dostupné z: http://www.mid.ru/web/guest/foreign_policy/ international_safety/conflicts/-/asset_publisher/xIEMTQ3OvzcA/content/id/324602.

MID. 2008b. „Stenogramma vystuplenija i otvetov na voprosy SMI Ministra inostrannych děl Rossii S. V. Lavrova po itogam peregovorov s Ministrom inostrannykh děl Respubliki Abkhaziya S. M. Šamboj, Moskva, 23 dekabrja 2008 goda." [online] Ministěrstvo inostrannych děl, 23. 12.2008 [cit. 13. 2. 2018]. Dostupné z: http://www.mid.ru/web/guest/foreign_policy/international_safety/conflicts/-/ asset_publisher/xIEMTQ3OvzcA/content/id/311638.

Minesashvili, S. 2018. „Common faith in scrutiny: Orthodoxy as soft power in Russian-Georgia relations." Pp 42-59 in A. Jödicke (ed.). Religion and Soft Power in the South Caucasus. New York: Routledge.

Mitrochin, N. 2004. Russkaja pravoslavnaja cerkov': sovremennoje sostojanije $i$ aktualnyje problemy. Moskva: Novoje literaturnoje obozrenije.

Mitrokhin, N., A. Nuritova, S. Kishkovsky. 2009. „,The Russian Orthodox Church in Contemporary Russia: Structural Problems and Contradictory Relations with the Government, 2000-2008. "Social Research: An International Quarterly 76 (1): 289-320.

Muchanov, V. 2016. „O tekuščem sostojanii cerkovnogo raskola v Abkhazii." Ježegodnik Instituta meždunarodnych issledovanij Moskovskogo gosudarstvennogo instituta meždunarodnych otnoshenij (Universiteta) Ministerstva inostrannych del Rossijskoj Federacii 15 (1): 129-137.

Newsru.com. 2009. „Žiteljam Južnoj Osetii perestali vydavat rossijskije pasporta.“ [online] Newsru.com, 5. 3. 2009 [cit. 13. 2. 2018]. Dostupné z: https://www.newsru.com/world/05mar2009/so_pasporta.html.

Nižegorodskaja mitropolija. 2007. „Archijepiskop Nižegorodskij i Aramasskij Georgiy vstretilsja s Prezidentom Respubliki Abchazii." [online] Nižegorodskaja mitropolija Russkoj pravoslavnoj cerkvi, 13. 9. 2007 [cit. 13. 2. 2018]. Dostupné z: http://nne.ru/news/arhiepiskop-nizhegorodskij-i-aramasskij-georgijvstretilsya-s-prezidentom-respubliki-abhazii-foto/.

Osetinskoje radio i televidenije. 2005a. „Otkrytoje pismo Jego Svjatějšestvu Svjatějšemu Patriarchu Moskovskomu i Vseja Rusi Aleksiju II." [online] Osetinskoje radio i televidenije, 16. 11. 2005 [cit. 13. 2. 2018]. Dostupné z: http://osradio.ru/religija/435-otkrytoe-pismo-ego-svjatejjshestvu-svjatejjshe mu.html.

Osetinskoje radio i televidenije. 2005b. „Obraščenije Pravoslavnoj Cerkvi Južnoj Osetii (Alanskoj Eparchii GPSCP)." [online] Osetinskoje radio $i$ televidenije, 16. 11. 2005 [cit. 13. 2. 2018]. Dostupné z: http://osradio.ru/religija/434-obrashhenie-pravoslavnojj-cerkvi-juzhnojj-osetii.html.

Payne, D. P. 2015. „Spiritual Security, the Russkiy Mir, and the Russian Orthodox Church: The Influence of the Russian Orthodox Church on Russia's Foreign Policy regarding Ukraine, Moldova, Georgia, and Armenia." Pp 65-70 in A. Hug a kol. Traditional religion and political power: Examining the role of the church in Georgia, Armenia, Ukraine and Moldova. London: The Foreign Policy Centre.

Pereverzev, I. 2011. „Lider partii ,Forum narodnogo jedinstva Abkhazii“ Raul' Chadžimba: ,Nam vsem segodnja nužno stremitsja k tomu, čtoby Abchazskaja Pravoslavnaja Cerkov' stala avtokefal'noj:“" [online] Portal - Credo.ru, 27. 06. 2011 [cit. 1. 1. 2017]. Dostupné z: http://www.portal-credo.ru/site/ ?act=authority\&id $=1658$.

Petro, N. 2015. „Russia's Orthodox Soft Power.“ [online] Carnegie Council, 23. 3. 2015 [cit. 1. 1. 2017]. Dostupné z: https://www.carnegiecouncil.org/publications/articles_papers_reports/727.

Pkhaladze, T. 2012. „RPC i Nezavisimaja Gruzija.“ Pp 155-173 In T. Pkhaladze a kol. Religion as the Instrument of Russian Foreign Policy towards Neighboring Countries Georgia, Latvia, Ukraine. Tbilisi: "Mtatsmindeli" Publishing House.

Prezident Južnoj Osetii. 2012. „Konstitucija (Osnovnoj zakon) Respubliki Južnaja Osetija. “ [online] Prezident Južnoj Osetii, 5. 7. 2012 [cit. 13. 2. 2018]. Dostupné z: http://presidentruo.org/konstituciyaosnovnoj-zakon-respubliki-yuzhnaya-osetiya/. 
Prezident Južnoj Osetii. 2013. „Ukaz ob utverždenii koncepcii nacionalnoj bezopasnosti Respubliki Južnaja Osetija." [online] Prezident Južnoj Osetii, 26. 9. 2013 [cit. 1. 2. 2018]. Dostupné z: http:// presidentruo.org/ukaz-ob-utverzhdenii-koncepcii-nacionalnoj-bezopasnosti-respubliki-yuzhnayaosetiya/.

Regnum. 2005. „Južnaja Osetija prosit Alexija II vzjat osetinskuju cerkov pod svoj omfor.“ [online] Regnum, 16. 2. 2005 [cit. 13. 2. 2018]. Dostupné z: https://regnum.ru/news/408148.html.

Regnum. 2011. „Alexandr Ankvab: ,Otnošenija Abchazii s Rossijej ne bazirujutsja na tom, čto bylo 150 let nazad!" [online] Regnum, 22. 08. 2011 [cit. 1. 12. 2017]. Dostupné z: https://regnum.ru/news/russia/ 1437495.html.

Richters, K. 2013. The Post-Soviet Russian Orthodox Church: Politics, Culture and Greater Russia. London: Routledge.

Rjabych, J. 2004. „Političeskije partii Rossii i Russkaja Pravoslavnaja Cerkov'“ Politia 32 (1): 124-148, https://doi.org/10.30570/2078-5089-2004-32-124-148.

RPC MP. 2005a. „Žurnaly zasedanija Svjaščennogo Sinoda ot 30 julja 2003 goda." [online] Russkaja pravoslavnaja cerkov', 16. 4. 2005 [cit. 13. 2. 2018]. Dostupné z: http://www.patriarchia.ru/db/text/ 4840988.html.

RPC MP. 2005b. „Jepiskop Stavropol'skij i Vladikavkazskij Feofan posetil Cchinval.“ [online] Russkaja pravoslavnaja cerkov', 22. 9. 2005 [cit. 13. 2. 2018]. Dostupné z: http://www.patriarchia.ru/db/text/ 41269.html.

RPC MP. 2005c. „Problemy svobody veroispovidanija v zonach konfliktov obsudili učastniki konferencii ,Sodružestva nepriznannych gosudarstv'." [online] Russkaja pravoslavnaja cerkov', 16. 9. 2005 [cit. 13. 2. 2018]. Dostupné z: http://www.patriarchia.ru/db/text/40453.html.

RPC MP. 2005d. „Jepiskop Stavropol'skij i Vladikavkazskij o svojom vizite v Južnuju Osetiju: ,Nikakich zajavlenij na religioznuju temu ja ne delal:" [online] Russkaja pravoslavnaja cerkov', 24. 9. 2005 [cit. 13. 2. 2018]. Dostupné z: http://www.patriarchia.ru/db/text/50306.html.

RPC MP. 2006. „Predstavitel' Moskovskogo Patriarchata vyražajet uverennost', čto narody Rossii i Gruzii ,sochranjat družbu, nesmotrja na vse politicheskije složnosti:“ [online] Russkaja pravoslavnaja cerkov', 9. 10. 2006 [cit. 13. 2. 2018]. Dostupné z: http://www.patriarchia.ru/db/text/150175.html.

RPC MP. 2007a. „Vlasti nepriznannoj Respubliki Južnaja Osetija rezko osudili včerašnij vizit KatolikosaPatriarcha vseja Gruzii Ilii II v Cchinvalskiy region." [online] Russkaja pravoslavnaja cerkov', 11. 4. 2007 [cit. 13. 2. 2018]. Dostupné z: http://www.patriarchia.ru/db/text/228080.html.

RPC MP. 2007b. „Po blagosloveniju Svjatejšego Patriarcha Alexija abchazskim detjam peredadut duchovnuju literaturu." [online] Russkaja pravoslavnaja cerkov', 9. 01. 2007 [cit. 13. 2. 2018]. Dostupné z: http:// www.patriarchia.ru/db/text/181095.html.

RPC MP. 2007c. „Episkop Feofan pereizbran členom obščestvennoj palaty RF.“ [online] Russkaja pravoslavnaja cerkov', 24. 12. 2007 [cit. 13. 2. 2018]. Dostupné z: http://www.patriarchia.ru/db/text/ 342901.html.

RPC MP. 2008a. „V Novoafonskom monastyre (Abchazija) prodolžajutsja krupnomasštabnyje remontnyje raboty." [online] Russkaja pravoslavnaja cerkov', 20. 3. 2008 [cit. 13. 2. 2018]. Dostupné z: http://www.patriarchia.ru/db/text/382904.html.

RPC MP. 2008b. „Čeljabinskije specialisty ustanavlivajut novyje kupola na chramach Novoafonskogo monastyrja v Abchazii." [online] Russkaja pravoslavnaja cerkov', 3. 10. 2008 [cit. 13. 2. 2018]. Dostupné z: http://www.patriarchia.ru/db/text/469011.html.

RPC MP. 2008c. „Sovět Abchazskoj eparchii zapretil gruzinskomu svjaščenniku soveršat bogosluženija na territorii Abchazii." [online] Russkaja pravoslavnaja cerkov', 11. 4. 2008 [cit. 13. 2. 2018]. Dostupné z: http://www.patriarchia.ru/db/text/390188.html.

RPC MP. 2008d. „Katolikos-Patriarch vseja Gruzii Ilija II: ,Ja isključaju vojennyj konflikt meždu Rossijej i Gruzijej:" [online] Russkaja pravoslavnaja cerkov', 13. 5. 2008 [cit. 13. 2. 2018]. Dostupné z: http://www.patriarchia.ru/db/text/406545.html.

RPC MP. 2008e. „Zajavlenije Svjatejšego Patriarcha Aleksija v svjazi s krovoprolitijem v Južnoj Osetii." [online] Russkaja pravoslavnaja cerkov', 8. 8. 2008 [cit. 13. 2. 2018]. Dostupné z: http:// www.patriarchia.ru/db/text/446334.html. 
RPC MP. 2008f. „Arkhijepiskop Stavropol'skij Feofan prinjal učastije v kruglom stole na temu ,Posle vojny na Kavkaze: scenarii i perspektivy“" [online] Russkaja pravoslavnaja cerkov', 26. 8. 2008 [cit. 13. 2. 2018]. Dostupné z: http://www.patriarchia.ru/db/text/452342.html.

RPC MP. 2008g. „Eduard Kokojty i archijepiskop Stavropol'skij i Vladikavkazskij Feofan obsudili plany okazanija gumanitarnoj pomošči naseleniju Južnoj Osetii. " [online] Russkaja pravoslavnaja cerkov', 30. 8. 2008 [cit. 13. 2. 2018]. Dostupné z: http://www.patriarchia.ru/db/text/453815.html.

RPC MP. 2008h. „Telekanal ,Spas‘ obyavil konkurs na lučšij architekturnyj projekt chrama dlja Abchazii i Yužnoj Osetii." [online] Russkaja pravoslavnaja cerkov', 21. 10. 2008 [cit. 13. 2. 2018]. Dostupné z: http://www.patriarchia.ru/db/text/477079.html.

RPC MP. 2009. „Archijepiskop Volokolamskij Ilarion: ,Političeskije razdelenija i izmenenije gosudarstvennych granic ne dolžny vesti k izmeneniju granic cerkovnych:" [online] Russkaja pravoslavnaja cerkov', 31. 10. 2009 [cit. 13. 2. 2018]. Dostupné z: http://www.patriarchia.ru/db/text/926233.html.

RPC MP. 2010a. „Patriaršeje pozdravlenije S. V. Bagapšu s pereizbranijem na post Prezidenta Respubliki Abchazija." [online] Russkaja pravoslavnaja cerkov', 12. 2. 2010 [cit. 13. 2. 2018]. Dostupné z: http://www.patriarchia.ru/db/text/1067235.html.

RPC MP. 2010b. „Patriaršeje pozdravlenije s 20-letiyem so dnja prinjatija Deklaracii o natsional’nom suverenitete Juzhnoj Osetii." [online] Russkaja pravoslavnaja cerkov', 20. 9. 2010 [cit. 13. 2. 2018]. Dostupné z: http://www.patriarchia.ru/db/text/1281205.

RPC MP. 2011. „Pozdravlenije Svjatějšego Patriarcha Kirilla novoizbrannomu Prezidentu Respubliki Abchazija A. Z. Ankvabu. " [online] Russkaja pravoslavnaja cerkov', 27. 8. 2011 [cit. 1. 1. 2019]. Dostupné z: http://www.patriarchia.ru/db/text/1606065.html.

RPC MP. 2017a. „Glava 1. Obščije položenija.“ [online] Russkaja pravoslavnaja cerkov', 2.12 .2017 [cit. 13.2.2018]. Dostupné z: http://www.patriarchia.ru/db/text/133115.html.

RPC MP. 2017b. „Pozdravlenije Svyatješego Patriarcha Kirilla A. I. Bibilovu s izbranijem na post Prezidenta Respubliki Juzhnaya Osetija." [online] Russkaja pravoslavnaja cerkov', 2. 12. 2017 [cit. 13.8. 2019]. Dostupné z: http://www.patriarchia.ru/db/text/4858725.html.

RPC MP. 2019. „Vnutrennjaja žizn' i vnešnjaja dejatel'nost' Russkoj Pravoslavnoj Cerkvi s 2009 goda po 2019 god." [online] Russkaja pravoslavnaja cerkov', 29. 01. 2019 [cit. 8. 9. 2019]. Dostupné z: http://www.patriarchia.ru/db/text/5359105.html.

Russkaja linija. 2008. „Archijepiskop Feofan poznakomil predstavitelja Jevrosojuza s situatsijej v Južnoj Osetii." [online] Russkaja pravoslavnaja cerkov', 13. 8. 2008 [cit. 13. 2. 2018]. Dostupné z: http:// rusk.ru/st.php?idar $=728027$.

Russkaja linija. 2009. „Alanskaja jeparchija obrečena na suščestvovanije." [online] Russkaja linija, 16. 9. 2009 [cit. 1. 1. 2019]. Dostupné z: http://ruskline.ru/news_rl/2009/9/16/alanskaya_eparhiya_ obrechena_na_suwestvovanie/.

Russkaja linija. 2011. „Sergey Šamba: ,My vse vystupajem za avtokefaliju؛“ [online] Russkaja linija, 16.05. 2011 [cit. 1. 12. 2017]. Dostupné z: http://ruskline.ru/news_rl/2011/05/16/sergej_shamba_my_vse_ vystupaem_za_avtokefaliyu/.

Sekritariat Alanskoj eparchii. 2008. „Kratkaya istoriko-analitičeskaja spravka sekretariata Alanskoj jeparchii IPC Grecii o jurisdiktsionnom i kanoničeskom položenii jepachii v složivšichsya geopoliticheskiich uslovijach." [online] Sekritariat Alanskoj eparchii, 17. 9. 2008 [cit. 13. 2. 2018]. Dostupné z: https:// credo.press $/ 95922 /$.

Semjonov, I. 2008. „Mitropolit Kirill: Russkaja i Gruzinskaja cerkvi mogut pomoč' preodolet' posledstvija vojny. " [online] Vesti, 9. 10. 2008 [cit. 1. 1. 2019]. Dostupné z: http://www.vesti.ru/doc.html?id=221973.

Shafiee, N., E. Fallahi. 2018. „The Church and Religious Diplomacy in Russia's Foreign Policy." Journal of Iran and Central Eurasia Studies 1 (1): 93-105. Silant’jev, R. 2007. „Religioznyj faktor vo vnešněpolitičeskich konfliktace na Kavkaze." Pp 130-150 in A. Malašenko, S. Filatov (eds.). Religija i konflikt. Moskva: ROSSPEN.

Soldatov, A. 2008. „Gorjačije točki pravoslavija.“ Ogonjok, 25. 8. 2008, p. 1.

Stoeckl, K. 2016. "The Russian Orthodox Church as Moral Norm Entrepreneur." Religion, State and Society 44 (2): 132-151, https://doi.org/10.1080/09637494.2016.1194010.

Svjaščennaja metropolija Abchazija. 2019. „Ekstrennoje zasedanije Soveta Svjaščennoj Mitropolii Abchazii." [online] Svjaščennaja mitropolija Abchazija, 4. 6. 2019 [cit. 11.11.2019]. Dostupné z: https:// anyha.org/aap-axeilak-ailatwara-04-05-2019/. 
Svjaščennaja metropolija Abchazija. nedat.a. „Pismo Prezidenta RA V.G. Argzinba Patriarchu Alexiju II (1997g.)." [online] Svjaščennaja metropolija Abchazija [cit. 13. 2. 2018]. Dostupné z: https://anyha.org/ v-g-ardzinba-isfquy-aleksi-ii-iaxj/.

Svjaščennaja metropolija Abchazija. nedat.b. „Pismo predsedatelja VS RA V. Ardzinba Patriarchu Alexiju II.“ [online] Svjaščennaja metropolija Abchazija [cit. 13. 2. 2018]. Dostupné z: https://anyha.org/ v-ardzynba-isfquy-apatriartx-alykjsa-ii-iaxj/.

Svjaščennaja metropolija Abchazija. nedat.c. „Pismo Patriarchu Aleksiju II. i Archierejskomu Soboru RPC ot predstavitelej mirjan Suchumo-Abchazskoj Eparchii (28.07.2000). " [online] Svjaščennaja metropolija Abchazija [cit. 13. 2. 2018]. Dostupné z: https://anyha.org/pismo-patriarxu-aleksiyu-ii-i-arxierejskomusoboru-rpc-ot-predstavitelej-miryan-suxumo-abxazskoj-eparxii-28-07-2000-g/.

Svjaščennaja metropolija Abchazija. nedat.d. „Pismo Patriarchu Aleksiju II. i Archierejskomu Soboru RPC ot rukovodstva Suchumo-Abchazskoj Eparchii (27.07.2000)." [online] Svjaščennaja metropolija Abchazija [cit. 13. 2. 2018]. Dostupné z: https://anyha.org/pismo-patriarxu-aleksiyu-ii-i-arxierejskomusoboru-rpc-ot-rukovodstva-suxumo-abxazskoj-eparxii-27-07-2000-g/.

Svjaščennaja metropolija Abchazija. nedat.e. „Pismo Prezidenta RA V. G. Argzinba Prezidentu RF V.V.Putinu po abchazskomu cerkovnomu voprosu." [online] Svjaščennaja metropolija Abchazija [cit. 13. 2. 2018]. Dostupné z: https://anyha.org/pismo-prezidenta-ra-v-g-ardzinba-prezidentu-rf-v-v-putinupo-abxazskomu-cerkovnomu-voprosu/.

Svjaščennaja mitropolija Abchazija. 2018. „Sotrudniki SMA prinjali učastije v sljote dobrovolcev Severnogo Kavkaza ,Zimnij Dobrograd؛“ [online] Svjaščennaja mitropolija Abchazija, 28. 11.2018 [cit. 1. 1. 2019]. Dostupné z: https://anyha.org/dobrograd-19/.

Šnirel'man, V. 2003. Vojny pamjati: mify, identičnost i politika v Zakavkazje. Moskva: Akademkniga.

Tjurenkov, M. 2019. „Na cholmach Gruzii i v gorach Abchazii: Čem ,ukrajinskaja avtokefalija‘ grozit Gruzinskoj cerkvi." [online] Tcar'grad, 10. 1. 2019 [cit. 11. 1. 2019]. Dostupné z: https://tsargrad.tv/ articles/chem-ukrainskaja-avtokefalija-grozit-gruzinskoj-cerkvi_177929?fbclid=IwAR0bRNkVSRbglF w4353RNblboHFAiI209nsvhtIfLh_g8MQ0iKl5cpPlRE.

Vernickij, A. 2008. „Putin rasskazal, kto podtolknul Tbilisi k agressii i grozit li miru ,cholodnaya voyna؛“" [online] Pervyj kanal, 11. 9. 2008 [cit. 13. 2. 2018]. Dostupné z: https://www.1tv.ru/news/2008-0911/181538putin_rasskazal_kto_podtolknul_tbilisi_k_agressii_i_grozit_li_miru_holodnaya_ voyna.

Vesti. 2009. „,Cerkov' i mir' od 24 oktjabrja 2009 goda.“ [online] Vesti, 24. 10.2009 [cit. 1. 12. 2017]. Dostupné z: https://www.vesti.ru/videos/show/vid/247258/www.vesti.ru/videos/show/vid/702650/cid/ $58 /$.

\section{O autorce}

Maria Avanesova v současnosti studuje na Katedře politologie a mezinárodních vztahů Západočeské univerzity v Plzni doktorský obor mezinárodní vztahy. Zabývá se otázkami působení Ruské pravoslavné církve v Rusku a v postsovětském prostoru a ruskou soft power.

\section{Summary}

The Russian Orthodox Church (ROC), whose activity in South Ossetia and Abkhazia is the topic of this paper, is considered to be the largest autocephaly Orthodox Church, which operates not only in Russia, but also beyond its borders. Close cooperation between the ROC and the Russian state inside Russia and support of the ROC in its activity on its canonical territory and beyond it on the part of Russian secular rule have given rise to discussions on the close link between the state and Church, and also on the possibility of the state's use of the ROC as a source of soft power. The example of South Ossetia and Abkhazia was not selected randomly. It is referred to as one of the few situations in which the positions of the state and Church significantly differ. The aim of this paper is to use the example of the ROC's relationship towards South Ossetia and Abkhazia to analyze the conformity of opinions between the ROC and the politics of the Russian state. In light of the fact that the aforementioned de facto states are a part of the jurisdiction of the Georgian Church, it means that for the ROC, similarly to the Russian state, it is an area of external activity. This means that this paper can be a contribution to the debate on the 
overall role of the ROC not only in post-Soviet space, but also in Russian foreign policy. The analysis was carried out in two directions. The first was the relationship of the ROC to the ecclesiastical affiliation of Abkhazia and South Ossetia. The official rhetoric of the representatives of the ROC was compared to the actual steps taken by the ROC, which were found in Russian and local media, or on the web pages of the churches. The second direction was the ROC's relationship towards the "statehood" of South Ossetia and Abkhazia. In regard to the fact that the policy of Russia's secular leadership is generally known, only marginal attention is paid to it. This work primarily focuses on the ROC's attitude towards Abkhazia and South Ossetia. The basis of sources for this paper was primarily formed by primary sources, not only including the official web pages of the state and church, but also the media.

The analysis has shown that the wars between Georgia and Abkhazia and South Ossetia at the beginning of the 1990s have led to a significant resistance to all things Georgian on the part of the inhabitants of Abkhazia and South Ossetia. The leadership of Abkhazia and South Ossetia saw independence from the Georgian Church as a tool to prove its overall independence from Georgia, which has reshaped the church issue into a political issue, thus making it impossible in practice for the Georgian Orthodox Church (GOC) in ecclesiastical life in Abkhazia and South Ossetia. Representatives of both de facto states have therefore looked for not only political but religious support from representatives of Russia and the ROC. After President Putin took the position as the head of the Russian Federation, Russia's condescending position towards these de facto states is beginning to be evident. Although on an official state level they are spoken about as a part of Georgia, on an unofficial level these regions have been supported. The opinion of the ROC's representatives on the issue of the "statehood" of Abkhazia and South Ossetia was unified - they were labeled as unacknowledged until 2008. In the available speeches made by Russia's highest ranking secular representatives, an evaluation of the ecclesiastical affiliation of both de facto states was not found. However, research showed that similar characteristics between the political position of Russian secular leadership towards Abkhazia and South Ossetia and the position of the ROC in terms of the ecclesiastical affiliation of Abkhazia and South Ossetia can be found. The ROC throughout the whole period spoke about the right of the GOC to Abkhazia and South Ossetia. However, the unofficial stance was different and the analysis showed that the stance towards South Ossetia was different than the stance on Abkhazia. Representatives of the ROC almost never intervened in the religious matters of South Ossetia. But, the ROC in Abkhazia did interfere in church affairs, communicating and consecrating religious members. During the war in 2008, there was no differing position between the representatives of Russian secular leadership and church leadership. The ROC, just like the Russian state, began to treat Abkhazia and South Ossetia as states. After Russia acknowledged Abkhazia and South Ossetia, church representatives continue to speak of the churches of Abkhazia and South Ossetia as a part of the GOC; however, they are beginning to acknowledge that the GOC cannot operate there, and it is necessary to help these de facto states. Similar but unofficial "aid" often disturbs the local population. It has been proven that the ROC intervenes significantly in the religious life of Abkhazia and South Ossetia. The analysis carried out for this paper does not allow us to claim that the position of the ROC and the Russian state differ. The only point which differs on a church and political level is the acknowledgment of the ecclesiastical affiliation of Abkhazia and South Ossetia. But, in regard to the fact that Russian secular officials have not commented on the affiliation of Abkhazia and South Ossetia, we cannot claim there is a disagreement between the positions of the ROC's representatives and members of Russian secular leadership. At the same time, this allows us to speak of the distinctly similar position of the Russian and Church towards Abkhazia and South Ossetia. 